Waal, B.M.E. de, Batenburg, R. What makes end-user training successful? A mixed method study of a business process management system implementation. International Journal of Knowledge and Learning: 2012, 8(1/2), 166-183

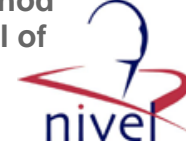

\begin{tabular}{|l|l|}
\hline $\begin{array}{l}\text { Postprint } \\
\text { Version }\end{array}$ & 1.0 \\
\hline Journal website & http://inderscience.metapress.com/content/r021412542176m47/ \\
\hline Pubmed link & \\
\hline DOI & $10.1504 /$ IJKL.2012.047569 \\
\cline { 2 - 2 }
\end{tabular}

This is a NIVEL certified Post Print, more info at http://www.nivel.eu

\title{
What makes end-user training successful? A mixed method study of a business process management system implementation
}

\author{
BENNY M.E. DE WAAL* \\ Research Centre for Innovation and Business, University of Applied Sciences Utrecht, \\ Padualaan 101, 3584 CH Utrecht, The Netherlands E-mail: benny.dewaal@hu.n I \\ *Corresponding author
}

\section{RONALD BATENBURG}

Netherlands Institute for Health Services Research, NIVEL, P.O. Box 1568, 3500 BN Utrecht, The Netherlands and Institute of Information and Computing Sciences, Utrecht University, P.O. Box 80089, 3508 TB Utrecht, The Netherlands E-mail: r.batenburg@nivel.nl

\begin{abstract}
:
Under what conditions is end-user training (EUT) as part of the implementation of a business process management (BPM) system successful? This question is addressed in this paper. Based on the literature on EUT and implementation success, we first argue that user involvement with, and attitude towards, a BPM system, both have a conditional effect on the relationship between EUT and the implementation success of the system. Secondly, we investigated this expectation empirically, by measuring the practice of EUT as perceived by endusers. Using a mixed method approach, survey data was collected from 143 endusers of a BPM system in a large Dutch social insurance organisation, and by 49 additional semi-structured interviews.

Regression analysis of the survey data shows that attitude variables indeed have a significant moderating influence on implementation success. In addition, the interviews revealed that specific attention must be paid to the arrangements for EUT when deploying BPM systems in this type of organisations. Arguments are given for a more comprehensive way of measuring and optimising EUT during the implementation of information systems/information technology in organisations.
\end{abstract}

\section{INTRODUCTION}

Early and intensive end-user training (EUT) is often advocated as a necessary part of the implementation of information systems and information technology (IS/IT). EUT 
Waal, B.M.E. de, Batenburg, R. What makes end-user training successful? A mixed method study of a business process management system implementation. International Journal of Knowledge and Learning: 2012, 8(1/2), 166-183

is described as "the teaching of skills to effectively use computer applications to endusers” (Gupta et al., 2010). Many studies have already shown that a lack of EUT is a major reason for a lack of IS/IT success, and that EUT is a key factor in the successful implementation and user acceptance of IS/IT (cf., Gallivan et al., 2005; Garcia-Sánchez and Pérez-Bernal, 2007; Igbaria et al., 1995; Sweeney et al., 2005). Although the relationship between EUT and implementation success is well documented (Sharma and Yetton, 2007), the concepts of EUT and implementation success vary a great deal between studies. For this reason, it is worth investigating the effects of different operationalisations of EUT and implementation success, and moreover, what conditions actually ensure the success of EUT.

In EUT research, there has been a great deal of emphasis on the learning process and the training methods used (cf., Gupta et al., 2010; Rajagopalan et al., 2007). When searching for practical studies on the relationship between EUT and implementation success in the IS/IT field, we found ten publications. A closer examination of these publications shows that many of the papers do not define their concepts explicitly in terms of measurements, factors or variables. Table 1 provides an overview of the ten selected papers and a summary of their measurements of EUT and implementation success, as well as their research methods and results.

From this overview, it becomes clear that the concept of EUT is measured in different ways. There is actually no one common measurement of EUT.

Measurements can include perceived experience, the amount of training or from whom the training is received. For implementation success, a number of papers do share a common measurement, i.e., system usage and user satisfaction are used in a number of cases. All of the studies, however, share the fact that a primarily positive effect of EUT on implementation success was confirmed by empirical analysis, some directly, some indirectly. Some of the studies recognised that the relationship between EUT and implementation success is more complex than these results suggest. In the study by Gallivan et al. (2005), for instance, no direct effect was found of the extension of EUT on system usage, nor of perceived training quality on system usage. If gender was taken out as a control variable, however, perceived training quality did have a positive effect on system usage. In this study, it appeared that women perceived training in a less favourable light than men. In another study by Leonard-Barton and Deschamps (1988), it was found that, specifically for users with low scores for innovativeness and computer skills, EUT had a positive effect on system usage. These results reinforce the expectation that in real work settings, situational factors are involved in the positive effect of EUT on implementation success.

Sharma and Yetton (2007) contributed to this argument through their finding that technical complexity and task interdependence both have a conditional influence on the effect of EUT on implementation success. Sharma and Yetton also found in a meta-analysis of empirical studies reported in journals, conference proceedings and unpublished dissertations that the effect of EUT on implementation success was a positive function of task interdependence and also of technical complexity. From the selected studies, it also appears that the respondent group in each was very different. The variation in the results may therefore be attributed to the different backgrounds of the respondents. 
Waal, B.M.E. de, Batenburg, R. What makes end-user training successful? A mixed method study of a business process management system implementation. International Journal of Knowledge and Learning: 2012, 8(1/2), 166-183

\section{[TABLE 1]}

For these reasons, it is worth taking a closer look at the practice of EUT during the implementation of IS/IT. In the studies above, EUT is mostly measured by quantity or intensity, and not using qualitative measures. Most of the studies were based on questionnaire surveys. In practice, however, EUT occurs under special conditions, in that it needs to be organised whilst the regular work continues. Given these circumstances, not only the amount of training is important, but also the quality of the training programme and its setting (Gallivan et al., 2005). In order to gain insight into how these practices work and are experienced by end-users, qualitative research would be more appropriate.

The cited studies also showed that users' attitudes towards the application in question affect the relationship between EUT and implementation success. Especially, research has shown that users' attitude is an important factor of implementation success of IS/IT (Barki and Hartwick, 1994; De Waal and Batenburg, 2009). Therefore, we believe that theories concerning end users' attitudes towards the system and user involvement should be added to research on the effects of EUT. In this research, we aim to understand the effect of EUT on implementation success by explicitly taking the practical arrangement of EUT and the system attitudes of users into account. The research question of this paper is: What is the relationship between perceived EUT and implementation success and how is it influenced when users' attitudes towards the system and user involvement are taken into account? Given the complexity of this research question, we used a mixed-methods approach (Creswell and Plano Clark, 2007) in order to both describe and explain the reality of EUT practices and the relationship with implementation success (Runeson and Höst, 2009).

In the next section, we will describe the way in which we conceptually modelled the research question in order to empirically test a number of expectations. Then, the data and methods for these tests will be explained. The research took place during the implementation of a business process management (BPM) system in a large Dutch social insurance organisation. Thereafter, we present the results of this quantitative study in order to investigate the question of what effects EUT has on implementation success, and the influence of users' attitude on these effects. Qualitative data will be presented in order to show how the training occurred. Finally, we reflect upon the results and draw conclusions and practical implications in the closing section.

\section{CONCEPTUAL MODEL}

From the literature, as discussed previously, we can assume that there is a positive relationship between user training and implementation success, but that the relationship between user training and implementation success can be influenced by the end-users' attitudes towards the system and user involvement. Several studies (Al-Gahtani and King, 1999; Igbaria et al., 1995; Leonard-Barton and Deschamps, 1988; Rouibah et al., 2009) have taken into account users' attitudes towards the system. The main findings of these studies are that attitudes have a moderating effect on user training and implementation success. Based on this research, the conceptual model presented in Figure 1 formed the basis of our quantitative study. 
Waal, B.M.E. de, Batenburg, R. What makes end-user training successful? A mixed method study of a business process management system implementation. International Journal of Knowledge and Learning: 2012, 8(1/2), 166-183

\section{[FIGURE 1]}

In order to explore the effect of different conceptualisations, the measurement of user training took place in two ways: the perceived quality of the training was measured through a user survey that will be described in the research methods section, while the perceived practice of user training was measured using an additional number of qualitative interviews, that are also presented below. In order to conceptualise implementation success, we used DeLone and McLean's (1992, 2003) (D\&M) model of IS success, which is commonly accepted and frequently used in research into the success of IS/IT. In this model, IS/IT success is presented through six interdependent constructs: 1 quality of information (e.g., completeness, ease of understanding, relevance) 2 system quality (e.g., usability, availability, reliability) 3 service quality (e.g., the empathy and responsiveness of the IT department) 4 use (intended or actual) 5 user satisfaction 6 net benefits (individual or organisational).

The authors assume that there is an association between these constructs in terms of process. In other words, they assume that quality constructs will directly affect IS/IT use and user satisfaction. In accordance with the literature on EUT and implementation success, we used user satisfaction and IS/IT use as measurements of implementation success. For IS/IT use, we used intention to use, not actual use. The reasons for this are twofold. First, the use of the BPM system was mandatory. Therefore, in this situation, actual use as such becomes an irrelevant factor, and is only loosely related to the end-user's appreciation of the system (Nelson and Cheney, 1987; Ward et al., 2005).

Second, because this was a study of the deployment of a new BPM system that was not fully in use at the time of data collection, its actual use is a less valid measurement, as it depends on many other practical factors such as technical implementation problems and other delays.

Our conceptual model proposes that the relationship between EUT and implementation success will be indirect, influenced by end-users' attitudes towards the system and/or user involvement. In the context of the implementation of IS/IT, these attitudes are measured using the accepted measurements developed by Barki and Hartwick (1989). The first measurement, user involvement, is defined as a psychological state of system users, i.e., as the importance and personal relevance of using a specific system. The second, the end-user's attitude towards the system, is generally conceptualised as an affective or evaluative judgment of some artefact. In practice, this measurement locates one's position on a bipolar affective or evaluative dimension, e.g., bad/good. In the literature, it has been proven that these attitudes have a positive effect on IS/IT success and acceptance (cf., Dwivedi et al., 2008; Venkatesh et al., 2003; Ward et al., 2005). The hypotheses that can be derived from our conceptual model (and which will be tested) are: H1 EUT has no direct relationship with implementation success.

H2 Attitude towards the system will mediate the direct relationship between EUT and implementation success.

H3 User involvement will mediate the direct relationship between EUT and implementation success. 
Waal, B.M.E. de, Batenburg, R. What makes end-user training successful? A mixed method study of a business process management system implementation. International Journal of Knowledge and Learning: 2012, 8(1/2), 166-183

\section{BPM IMPLEMENTATION IN A DUTCH SOCIAL INSURANCE ORGANISATION}

In order to investigate our research questions, a holistic case study was performed within a Dutch governmental organisation that was set up to deliver social insurance to employees. According to Yin (2009), a case study gives the possibility to investigate contemporary phenomena in their context; in this case the practice of EUT during the implementation of a BPM system.

The organisation is an independent policy agency that reports to the Dutch Ministry of Social Affairs. It is a large, bureaucratic, administrative organisation that is responsible for executing social security regulations nationwide. The organisation controls all of the administrative and financial processes that are used in the execution of these regulations, and is also assigned to control misuse and fraud. During the study in 2008, the organisation had 15,834 employees (13,332 fte) under contract.

The data collection took place within the claims department of the organisation, which is located in six regions. The focus of the claims department is to examine clients' medical and work capabilities and to judge the claims of the clients within the scope of Dutch law. This department employs over 6,000 people.

In 2007, a new way of working was introduced in order to support the front office and to integrate existing applications. As an important part of this event, a BPM system was initiated. This BPM system was primarily aimed to streamline the primary administrative processes which are based on the laws on social security and to improve the quality of the company in terms of its compliance with (primarily legalistic) rules and procedures. In addition to achieving higher levels of efficiency and service quality, the goal of the BPM project was also to achieve uniformity in case handling. Teams were created by bringing together four different types of job category: team support employees; process support employees; job consultants; and medical insurance doctors. This research focused on these job categories.

The project organisation consisted of a steering group supported by a sounding board and a project quality group. The steering group was responsible for the end result and consisted of senior users, senior developers, a representative of the user organisation, a project advisor and the project manager. The sounding board was responsible for the definition of the requirements of the user organisation and the acceptance of business products. This group consisted of managers and employees of the user organisation, one end-user, a quality advisor and a development manager. It was agreed that members of the sounding board would pass information on to the employees they represented. The project quality group was responsible for monitoring the quality aspects and the deliveries of the project. Its members consisted of quality advisors and domain experts.

The overall responsibility of the project manager was to ensure that the project delivered the right products within the appointments that had been made. The training of the employees was based on the 'train the trainer' principle. A selected group of end-users was trained to become mentors and subsequently to support other end-users. The training for the end-users predominantly consisted of system training and team training. The training took two full working days. After the training, is was expected that the users could gradually become familiar with the system in practice. 
Waal, B.M.E. de, Batenburg, R. What makes end-user training successful? A mixed method study of a business process management system implementation. International Journal of Knowledge and Learning: 2012, 8(1/2), 166-183

In the period after the training, support was given by the mentors on a daily basis. During the first weeks of the training, support was provided on one or two days by professional trainers.

\section{RESEARCH METHOD}

\subsection{Data collection}

In order to gain answer our research question a mixed method approach including methodological triangulation was applied (cf., Creswell and Plano Clark, 2007; Lister, 2005). Written surveys and face to face interviews carried out in phases in May-June 2008 in six offices. The questionnaire was distributed via the Internet. It turned out that not all of the team support and process support employees had full access to all internet sites and applications. For this group, alternative ways to fill out the questionnaire were organised, such as completing the questionnaire on a different computer or using a paper-based version.

In addition to the survey, 49 face to face interviews were held with end-users. The interviewees were selected by the change agent at the office. The interviews also took place in May and June 2008, and were conducted at the office of the insurance company.

The guidelines for the semi-structured interviews were followed for the most part, but depending on the answers recounted by the participants, deviations occurred. The interviews were tape-recorded, and a report was made of each interview (Patton, 2002).

This report was sent to the interviewee for approval. Comments and corrections were discussed if necessary and incorporated.

\subsection{User survey}

The number of respondents was 143, indicating a response rate of 30\%. This response appeared to be unbiased according to job category, which was the main criterion for stratification. The sample consisted of $13 \%$ team support employees, $21 \%$ process support employees, $42 \%$ job consultants and $24 \%$ medical insurance doctors, which is largely representative of the organisation as a whole. Of the respondents, $60.1 \%$ were male and $39.9 \%$ were female. The average age was 48.5 years old (ranging from 22 to 65 years old). The respondents had been employed by the organisation for an average of 19 years, ranging from one to 41 years. Over 35\% of the respondents indicated that they had better-than-average computer skills, in comparison to their colleagues. Slightly more than half of the respondents stated that they had average computer skills. Regarding the BPM system, 25.9\% of the respondents stated that they had better-than-average computer skills. Finally, 27.3\% of the respondents held a university degree.

In order to measure perceived EUT (the initial independent variable in our model) through the user survey, one single item from the study by Sanders and Courtney (1985) was used, i.e., “The training given was sufficient”. This item had four answer categories ( 1 = fully disagree, 4 = fully agree).

System implementation success (i.e., one of the dependent variables) was measured using the concepts of intention to use and user satisfaction. The intention to use concept was measured using one item, i.e., "If the system was not mandatory, I would still use it”, as suggested by Seddon and Kiew (1996). This item also had four answer categories. 
Waal, B.M.E. de, Batenburg, R. What makes end-user training successful? A mixed method study of a business process management system implementation. International Journal of Knowledge and Learning: 2012, 8(1/2), 166-183

User satisfaction (another dependent variable indicating success) was measured using a number of items that were validated as a single dimensional scale developed by Shaw et al. (2002). In order to apply this to our dataset, factor analysis was performed in order to analyse the construct validity of the group of eight items. Principal component analysis (PCA) with promax rotation resulted in a two-factor solution with eigenvalues of 4.26 and 1.69 , which accounted for $53.2 \%$ and $21.1 \%$ respectively of the overall variance. The eight items loaded distinctively on either of the two constructs, indicating appropriate discriminant validity. The factor loadings were between 0.770 and 0.950 , which can be considered as being very significant (Hair et al., 1992). The reliability of the two scales, the four-item information satisfaction scale and the four-item service satisfaction scale, was confirmed by Cronbach's alphas of 0.92 and 0.84 respectively (cf., Nunnally, 1978). The items of the scale also had four answer categories.

Attitude towards the system (one of the moderating variables in the model) was measured using four items from a scale developed by Hartwick and Barki (1994). They developed seven-point scale items by which users could judge the IS/IT application by contrasting labels such as 'good/bad', 'terrible/terrific', 'useful/useless' and 'worthless/valuable'. PCA showed that the four items clearly loaded on one factor, with an eigenvalue of 3.21 and an overall variance of $80.2 \%$. The reliability of the scale was confirmed by a Cronbach's alpha of 0.92.

In order to measure user involvement (the other moderating variable in the model), five items from the study by Hartwick and Barki (1994) were used. They defined the concept of user involvement using items that express judgments of the IS/IT application in terms of 'important/not important', 'relevant/irrelevant', 'fundamental/trivial', 'essential/non-essential' and 'significant/insignificant' on a seven-point scale. For this dataset, PCA on the items showed that there was one strong latent factor (eigenvalue 3.36, overall variance 67.3\%). Reliability analysis supported the scalability of the item set with a Cronbach's alpha of 0.88 .

\subsection{User interviews}

In addition to the user survey, a total of 49 employees were interviewed. In order to gather the same amount of data from each job type, the interviewees were almost equally distributed over the job categories. Of the interviewees, 13 were team support employees, 12 were process support employees, 13 were job consultants and 11 were medical insurance doctors. A large number of the interviewees (30) were mentors during the implementation of the system. The mentor role was allocated employees to support end users during implementation through the train-the-trainer principle (cf., Igbaria et al., 1995).

The analysis of the interviews occurred in the following manner (Boeije, 2002; Miles and Huberman, 1994; Neuman, 2002). Each interview report within a certain job category was read carefully by the researchers in order to determine meaningful fragments of text. These fragments were coded using open coding. Fragments of text from within one interview and between interviews within the same job category were compared in order to determine whether or not they had the same code. If necessary, it was decided to merge codes or to change a fragment to another code following an axial coding procedure. This procedure was repeated for the other job categories. Thereafter, the fragments and codes of the four job categories were compared. In addition, when necessary, changes were made to codes and fragments were replaced. The last step was to structure the codes as main- and sub-codes using selective 
Waal, B.M.E. de, Batenburg, R. What makes end-user training successful? A mixed method study of a business process management system implementation. International Journal of Knowledge and Learning: 2012, 8(1/2), 166-183

coding. This resulted in a structured identification of fragments relating to the different elements of EUT.

\section{RESULTS}

\subsection{Results of user survey}

As described above, the main hypothesis that was tested using the user survey data concerns the relationship between perceived EUT and implementation success and the moderating effect of users' attitudes towards and user involvement in the system. Assuming linearity, we can model this hypothesis into a regression equation in which user involvement and attitude towards the system are pure moderators, influencing the shape of the relationship between perceived EUT and implementation success (cf., Sharma et al., 1981). The regression model can be written as:

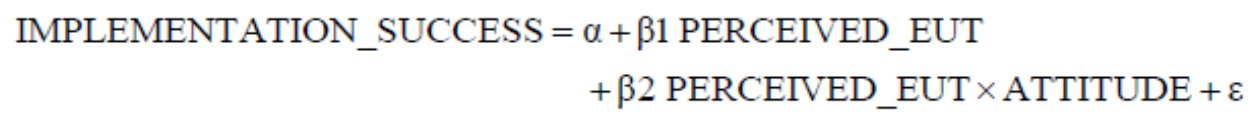

From this equation, it is to be expected that the main effect of perceived EUT ( $\beta 1)$ will be not significant, and we also explored whether the interaction effect between perceived EUT and attitude ( $\beta 2)$ had an additional (net) significant effect, in accordance with the hypotheses. Before presenting the subsequent results of the regression analyses, we and intention to use) and the independent variable (perceived EUT) were normally distributed. The basic descriptives of the variables are described in Table 2.checked that both the dependent variables (information satisfaction, service satisfactionand intention to use) and the independent variable (perceived EUT) were normally distributed. The basic descriptives of the variables are described in Table 2.

\section{[TABLE 2]}

Next, we tested our regression model to ensure that the error terms were normally distributed and not significantly correlated with the predictors, which are the main indicators of heteroscedascity. The results of the regression analyses that test our hypotheses are presented in Table 3.

\section{[TABLE 3]}

a negative and significant effect on intention to use. It also appears, however, that the interaction effect of both attitudes on intention to use is positive and significant. This means that user involvement and attitude towards the system do indeed have an influence on the relationship between perceived EUT and intention to use. The same is true if information and service satisfaction are taken as dependent variables. In this study, no main effect was found between perceived EUT and satisfaction. However, the interaction effects are - once again - positive and significant, showing that users' attitudes have an effect on the relationship between EUT and implementation success. In conclusion, these results support Hypotheses 2 and 3, that EUT has a positive relationship with implementation success when end-users have positive attitudes towards the system.

Hypothesis 1 is also supported if information and service satisfaction is the dependent variable. With regard to intention to use, hypothesis 1 is not supported. In fact, the results were in the opposite direction. These findings contradict most results 
Waal, B.M.E. de, Batenburg, R. What makes end-user training successful? A mixed method study of a business process management system implementation. International Journal of Knowledge and Learning: 2012, 8(1/2), 166-183

presented in Table 1 and support the notion that more situational factors of EUT practice must be taken into account in order to determine the effect of EUT on implementation success (Gallivan et al., 2005). In the next section, we will explore these factors by presenting the qualitative analysis of the interviews.

\subsection{Results of user interviews}

What happens during the process of user training that causes the distinction between users with positive and negative attitudes, which then directs the effect of perceived EUT on the success of BPM implementation? The 49 semi-structured interviews that were conducted within the social insurance organisation during the implementation and training process can shed light on the answers to this question.

In Table 4, a summary is given of the interviews based on the positive and negative text fragments that were mentioned by the interviewees and pronouncements that, in the interpretation of the researchers, stood out. As can be seen, only a small number of the statements were positive. The majority of the statements of all four job categories were negative, especially about training procedure and training environment.

\section{[TABLE 4]}

As described in Section 3, the set-up of the training was designed so that users would learn the system functions first, and then gradually learn more about the system in practice. According to the interviewees, however, this created a feeling that one was learning too little in too many ways. One process support employee stated: "You could click on some trial and receive explanations about the system, but in practice it is different. What should you do if you make a mistake, how can you go back? On practical questions, you got no answer". The interviews made it clear that the training could be more practical and understandable. The interviews produced positive results with regard to the organisation of the team training. Some interviewees stated that it was "good that you got an overview of the work of other staff members", while others were also critical of this aspect: "You do not need to know much about what team support and process support employee do". According to the interviewees, team-oriented work was not initiated, although this was an explicit goal of the project.

Furthermore, it was reported by the interviewees that, during the training sessions, various problems arose involving the logistics of the training sessions, the lack of knowledge of some of the trainers and the incompleteness of the training environment.

The interviewees were, however, generally positive about the course material. Some saw it as annoying that the version of the BPM system was, in practice, quite different to its release in the training. Finally, the end-users were confronted with the fact that they were behind schedule with regard to their work, which carried on during the training. There was no extra time allocated for training, while a large majority of the interviewees considered that the time allocated for the training was too short.

The mentors indicated that their knowledge was actually not much greater than that of the end-users. As they all had a lot of questions at the beginning and the professional trainers were not present every day, this was experienced as being problematic. Hence, learning in practice after the training sessions was met with varying degrees of success. 
Waal, B.M.E. de, Batenburg, R. What makes end-user training successful? A mixed method study of a business process management system implementation. International Journal of Knowledge and Learning: 2012, 8(1/2), 166-183

End-users had insufficient experience with the system, among other reasons, because there were not enough training cases on the system.

With regard to their attitudes towards the BPM system, the interviews indicated that a minority of the respondents had positive opinions of the system. This group indicated that the system project group attempted to create a good system. However, the majority was sceptical about the system. They indicated that not all employees had sufficient experience with the BPM system, and wondered for how long the system would continue to be used. One process support employee said: "Nobody is happy with the system. When management does not make a decision, the system will slowly die. Everyone will find a different way to do his work”.

These interview findings indicate that, for most of the interviewees, the process of user training was not what they expected. End-users felt strongly that they lacked the expertise to use the system in practice, because the time and conditions for learning the system (including the training procedure, training environment and trainers) was insufficient. The majority had negative attitudes towards the system. Only a small number of the employees welcomed the system. We consider this as a valuable explanation for the empirical finding that no main effect or a significant negative main effect of EUT was found on implementation success in our regression analysis, based on the user survey. In a similar vein, the interview results support the notion that a positive effect of EUT was found only under certain conditions, i.e., when the end-users initially had a positive attitude towards the (BPM) system and the implementation project as a whole, as some of the positive quotations illustrate.

\section{CONCLUSIONS, IMPLICATIONS AND FURTHER RESEARCH}

In this study, the conditional effect of EUT on implementation success was investigated, as perceived by individuals when using a BPM system. In particular, we investigated whether or not the effect of EUT is moderated by user involvement with and attitude towards the system, and how the practice of EUT was perceived by endusers. Data were collected through a mixed method approach, i.e., by a survey among 143 end-users, and 49 additional semi-structured interviews with end-users, within a large Dutch social insurance organisation that had implemented a new BPM system. For the survey, validated scales were used to measure the key concepts of our conceptual model, and also the independent and dependent variables.

The first result of the quantitative analysis based on the survey data show that, in two out of the six regression models, EUT actually has a negative effect on intention to use as an indicator of implementation success. In the other regression models, the main effect of EUT on user satisfaction is not significant. Then the second result of the survey supports the hypothesis that there is indeed an interaction effect of users involvement and attitude towards the system, on indicators of implementation success. As expected, specifically for end-users with a positive attitude the positive effect of EUT on implementation success is significant.

A qualitative analysis of the interviews furthermore supported the expectation that practical arrangements for the user training are highly relevant conditions for the potential positive effect of EUT on implementation success. In the case study, several arrangements, such as training time, training procedure and training environment, appeared to be poorly organised. This problem was partly overcome and compensated for if the end-users started with a positive attitude towards the system. Users who began with a negative attitude, however, reduced the chance of 
Waal, B.M.E. de, Batenburg, R. What makes end-user training successful? A mixed method study of a business process management system implementation. International Journal of Knowledge and Learning: 2012, 8(1/2), 166-183

implementation success, as during the training, their user satisfaction and intention to use were reduced. From this, we can also conclude that during EUT, the arrangements for the training actually constitute an important condition - and that users' attitudes towards the system is an important moderator to achieve successful effects of EUT.

The results have implications for further research on EUT and implementation success. The mixed-methods approach (as used in this research) proved to be useful in that it provided a complete overview of the training as it was carried out. This additional information provided an opportunity to fully explain EUT practice and its impact on implementation success. Therefore, we can argue for a more comprehensive method of measuring EUT during the implementation of IS/IT. This measurement should consist of all of the elements of EUT (method, amount of training, training environment and materials, trainee-trainer interaction, quality of trainer and training time) and should be conducted using both quantitative and qualitative methods.

Another interesting question that emerged from this case study concerns the way in which attitudes towards a system can be enhanced during the process of system development and implementation. Research on user participation has shown that there is a relationship between specific types of user participation and system attitudes, but that more research is needed (cf., Markus and Mao, 2004). It would be particularly interesting to investigate what type of user participation is needed to make EUT more successful.

Finding the optimal type of EUT and user participation would make the implementation of systems more successful.

These further research questions are captured by the unified theory of IS implementation, devised by Yetton et al. (1999). In this theory, implementation success is contingent upon the context of implementation. Depending on the context, specific attention should be paid to the characteristics of the system and managerial support actions. Yetton et al. distinguish between individual impact and group impact as contingencies of IS/IT implementation. If the system has more impact on the individual level, more attention needs to be paid to the design stage prior to the implementation stage. If the system is expected to have more impact on the group level, a higher level of effort from management is required during the implementation phase. In this case study, the implementation of the BPM system within the social insurance organisation had a particularly powerful impact on the group level. Hence, it is to be expected that much more attention was paid to managerial support actions, including well-organised training conditions, in order to achieve implementation success. It appears from this study that this was not the case. Both the quantitative and qualitative analyses show that the attitude of users is critical with regard to the potential contribution of EUT to implementation success. In practice, this means that the arrangements for EUT must be managed before the training starts and that they must be customised for different implementation participants in order to be successful, as most of the literature suggests. Therefore, further research is needed in order to find the optimal type of training for the different participants. Taken into account, these theoretical considerations will improve the current research on EUT. 
Waal, B.M.E. de, Batenburg, R. What makes end-user training successful? A mixed method study of a business process management system implementation. International Journal of Knowledge and Learning: 2012, 8(1/2), 166-183

\section{REFERENCES}

Al-Gahtani, S.S. and King, M. (1999) 'Attitudes, satisfaction and usage: factors contributing to each in the acceptance of information technology', Behaviour \& Information Technology, Vol. 18, No. 4, pp.277-297.

Barki, H. and Hartwick, J. (1989) 'Rethinking the concept of user involvement', MIS Quarterly, Vol. 13, No. 1, pp.53-63.

Barki, H. and Hartwick, J. (1994) 'Measuring user participation, user involvement, and user attitude', MIS Quarterly, Vol. 18, No. 1, pp.59-82.

Boeije, H. (2002) 'A purposeful approach to the constant comparative method in the analysis of qualitative interviews', Quality \& Quantity, Vol. 36, No. 4, pp.391-409.

Creswell, J. and Plano Clark, V. (2007) Designing and Conducting Mixed Methods Research, Sage Publications, Thousand Oaks.

De Waal, B.M.E. and Batenburg, R.S. (2009) 'Do users go with the new workflow? From user participation to quality of work during WFM deployment', ECIS 2009: Proceedings of the

17th European Conference on Information Systems, 8-10 June, Verona, Italy, pp.24562467.

Delone, W.H. and McLean, E.R. (1992) 'Information systems success: the quest for the dependent variable', Information Systems Research, Vol. 3, No. 1, pp.60-95.

DeLone, W.H. and McLean, E.R. (2003) 'The DeLone and McLean model of information systems success: a ten-year update', Journal of Management Information Systems, Vol. 19, No. 4, pp.9-30.

Dwivedi, Y., Williams, M.D., Lal, B. and Schwarz, A. (2008) 'Profiling adoption, acceptance and diffusion research in the information systems discipline', ECIS 2008: Proceedings of the 16th

European Conference on Information Systems, Galway, Ireland, pp.1204-1215.

Gallivan, M.J., Spitler, V.K. and Koufaris, M. (2005) 'Does information technology training really matter? A social information processing analysis of coworkers' influence on IT usage in the workplace', Journal of Management Information Systems, Vol. 22, No. 1, pp.153192.

Garcia-Sánchez, N. and Pérez-Bernal, L.E. (2007) 'Determination of critical success factors in implementing an ERP system: a field study in Mexican enterprises', Information Technology

for Development, Vol. 13, No. 3, pp.293-309.

Gupta, S., Bostrom R.P. and Huber, M. (2010) 'End-user training methods: what we know, need to know', The DATA BASE for Advances in Information Systems, Vol. 41, No. 4, pp.9-39.

Hair, J.F., Anderson, R.E., Tatham, R.L. and Black, W.C. (1992) Multivariate Data Analysis with

Readings, 3rd ed., Macmillan, New York.

Hartwick, J. and Barki, H. (1994) 'Explaining the role of user participation in information system use', Management Science, Vol. 40, No. 4, pp.440-465.

Igbaria, M., Guimaraes, T. and Davis, G.B. (1995) 'Testing the determinants of microcomputer usage via a structural equation model', Journal of Management Information Systems, Vol. 11, No. 4, pp.87-114.

Igbaria, M., Zinatelli, N., Cragg, P. and Cavaye, A.L.M. (1997) 'Personal computing acceptance factors in small firms: a structural equation model', MIS Quarterly, Vol. 21, No. 3, pp.279-305.

Leonard-Barton, D. and Deschamps, I. (1988) 'Managerial influence in the implementation of new technology', Management Science, Vol. 34, No. 10, pp.1252-1265.

Lister, R. (2005) 'Mixed methods: positivists are from Mars, constructivists are from Venus', ACM

SIGCSE Bulletin, Vol. 37, No. 4, pp.18-19.

Markus, M.L. and Mao, J-Y. (2004) 'Participation in development and implementation updating an old, tired concept for today's IS contexts', Journal of the Association for Information

Systems, Vol. 5, Nos. 11-12, pp.514-544. 
Waal, B.M.E. de, Batenburg, R. What makes end-user training successful? A mixed method study of a business process management system implementation. International Journal of Knowledge and Learning: 2012, 8(1/2), 166-183

Miles, M.B. and Huberman, A. (1994) Qualitative Data Analysis: An Expanded Sourcebook, Sage Publications, Thousand Oaks.

Nelson, R.R. and Cheney, P.H. (1987) 'Training end users: an exploratory study', MIS Quarterly, Vol. 11, No. 4, pp.547-559.

Neuman, W.L. (2002) Social Research Methods: Qualitative and Quantitative Approaches, Pearson Education, Boston.

Nunnally, J. (1978) Psychometric Theory, McGraw-Hill, New York.

Patton, M.Q. (2002) Qualitative Research and Evaluation Methods, Sage Publications, Thousand Oaks.

Rajagopalan, B., York, K.M., Doane, D.P. and Tanniru, M. (2007) 'Enablers of enterprise training success - an exploratory investigation', International Journal of Business Information

Systems, Vol. 2, No. 3, pp.250-265.

Rouibah, K., Hamdy, H.I. and Al-Enezi, M.Z. (2009) 'Effect of management support, training, and user involvement on system usage and satisfaction in Kuwait', Industrial Management \& Data

Systems, Vol. 109, No. 3, pp.338-356.

Runeson, P. and Höst, M. (2009) 'Guidelines for conducting and reporting case study research in software engineering', Empirical Software Engineering, Vol. 14, No. 2, pp.131164.

Sanders, G.L. and Courtney, J.F. (1985) 'A field study of organizational factors influencing DSS success', MIS Quarterly, Vol. 9, No. 1, pp.77-93.

Seddon, P.B. and Kiew, M.Y. (1996) 'A partial test and development of Delone and McLean's model of IS success', Australasian Journal of Information Systems, Vol. 4, No. 1, pp.90-109.

Sharma, R. and Yetton, P. (2007) 'The contingent effects of training, technical complexity, and task interdependence on successful information system implementation', MIS Quarterly, Vol. 31, No. 2, pp.219-238.

Sharma, S., Durand, R.M. and Gur-Arie, O. (1981) 'Identification and analysis of moderator variables', Journal of Marketing Research, Vol. 18, No. 3, pp.291-300.

Shaw, N.C., DeLone, W.H. and Niederman, F. (2002) 'Sources of dissatisfaction in end-user support: an empirical study', The DATA BASE for Advances in Information Systems, Vol. 33, No. 2, pp.41-56 Sweeney, E., Evangelista, P. and Passaro, R. (2005) 'Putting supplychain learning theory into practice: lessons from an Irish case', International Journal of Knowledge and Learning, Vol. 1, No. 4, pp.357-372.

Venkatesh, V., Morris, M.G., Davis, G.B. and Davis, F.D. (2003) 'User acceptance of information technology: toward a unified view', MIS Quarterly, Vol. 27, No. 3, pp.425-478.

Ward, K.W., Brown, S.A. and Massey, A.P. (2005) 'Organisational influences on attitudes in mandatory system use environments: a longitudinal study', International Journal of Business

Information Systems, Vol. 1, Nos. 1/2, pp.9-30.

Yaverbaum, G.J. and Nosek, J. (1992) 'Effects of information system education and training on user satisfaction', Information \& Management, Vol. 22, No. 4, pp.217-225.

Yetton, P., Sharma, R. and Southon, G. (1999) 'Successful IS innovation: the contingent contributions of innovation characteristics and implementation', Journal of Information

Technology, Vol. 14, No. 1, pp.53-68.

Yin, R.K. (2009) Case Study Research, Sage Publications, Thousand Oaks. 
Waal, B.M.E. de, Batenburg, R. What makes end-user training successful? A mixed method study of a business process management system implementation. International Journal of Knowledge and Learning: 2012, 8(1/2), 166-183

TABLES AND FIGURE

Table 1 Studies on EUT and implementation success by method and result

\begin{tabular}{|c|c|c|c|}
\hline Study reference & Measurement of EUT & $\begin{array}{c}\text { Measurement of } \\
\text { implementation success }\end{array}$ & Method and result \\
\hline \multirow[t]{2}{*}{$\begin{array}{l}\text { Sanders and } \\
\text { Courtney (1985) }\end{array}$} & \multirow{2}{*}{$\begin{array}{l}\text { Question regarding } \\
\text { whether the training } \\
\text { was sufficient to utilise } \\
\text { decision support system } \\
\text { (DSS) }\end{array}$} & \multirow[t]{2}{*}{$\begin{array}{l}\text { User satisfaction, } \\
\text { decision-making } \\
\text { satisfaction }\end{array}$} & $\begin{array}{l}\text { Survey of } 378 \text { DSS } \\
\text { users (managers and } \\
\text { non-managers) }\end{array}$ \\
\hline & & & $\begin{array}{l}\text { Positive correlation } \\
\text { between EUT and both } \\
\text { success measures }\end{array}$ \\
\hline \multirow[t]{3}{*}{$\begin{array}{l}\text { Nelson and } \\
\text { Cheney (1987) }\end{array}$} & \multirow{3}{*}{$\begin{array}{l}\text { Total number of hours } \\
\text { of training, total } \\
\text { number of times a } \\
\text { specific training } \\
\text { technique was } \\
\text { experienced and a } \\
\text { quality rating for each } \\
\text { training technique }\end{array}$} & \multirow{3}{*}{$\begin{array}{l}\text { Ability to use the } \\
\text { system, system usage, } \\
\text { user satisfaction }\end{array}$} & $\begin{array}{l}\text { Interview and survey of } \\
100 \text { users }\end{array}$ \\
\hline & & & $\begin{array}{l}\text { Positive correlation } \\
\text { between EUT and ability } \\
\text { to use the system }\end{array}$ \\
\hline & & & $\begin{array}{l}\text { No correlation between } \\
\text { EUT and system usage or } \\
\text { user satisfaction }\end{array}$ \\
\hline \multirow{2}{*}{$\begin{array}{l}\text { Leonard-Barton } \\
\text { and Deschamps } \\
\text { (1988) }\end{array}$} & \multirow[t]{2}{*}{$\begin{array}{l}\text { Dichotomous variable: } \\
\text { yes/no }\end{array}$} & \multirow[t]{2}{*}{ System usage } & $\begin{array}{l}\text { Telephone survey of } \\
93 \text { salespeople }\end{array}$ \\
\hline & & & $\begin{array}{l}\text { Positive correlation } \\
\text { between EUT and system } \\
\text { usage, but only for 'low' } \\
\text { groups with regard to } \\
\text { individual variables, such } \\
\text { as innovativeness and } \\
\text { computer skills }\end{array}$ \\
\hline \multirow[t]{2}{*}{$\begin{array}{l}\text { Yaverbaum and } \\
\text { Nosek (1992) }\end{array}$} & \multirow[t]{2}{*}{$\begin{array}{l}\text { Participation in an MIS } \\
\text { introductory course }\end{array}$} & \multirow[t]{2}{*}{ User satisfaction } & $\begin{array}{l}\text { Survey of } 73 \text { graduate } \\
\text { students }\end{array}$ \\
\hline & & & $\begin{array}{l}\text { EUT leads to changes in } \\
\text { user satisfaction, but these } \\
\text { are not always positive }\end{array}$ \\
\hline
\end{tabular}


Waal, B.M.E. de, Batenburg, R. What makes end-user training successful? A mixed method study of a business process management system implementation. International Journal of Knowledge and Learning: 2012, 8(1/2), 166-183

Table 1 Studies on EUT and implementation success by method and result (continued)

\begin{tabular}{|c|c|c|c|}
\hline Study reference & Measurement of EUT & $\begin{array}{c}\text { Measurement of } \\
\text { implementation success }\end{array}$ & Method and result \\
\hline \multirow[t]{2}{*}{$\begin{array}{l}\text { Igbaria et al. } \\
(1995)\end{array}$} & \multirow{2}{*}{$\begin{array}{l}\text { Extent of training } \\
\text { received from college } \\
\text { courses, vendor } \\
\text { training, in-house } \\
\text { training and self- } \\
\text { training }\end{array}$} & \multirow{2}{*}{$\begin{array}{l}\text { Perceived usage, } \\
\text { variety of use, } \\
\text { perceived ease of } \\
\text { use and perceived } \\
\text { usefulness }\end{array}$} & $\begin{array}{l}\text { Survey of } 214 \text { part-time } \\
\text { MBA students }\end{array}$ \\
\hline & & & $\begin{array}{l}\text { EUT has direct and } \\
\text { indirect effects on all } \\
\text { dependent variables }\end{array}$ \\
\hline \multirow[t]{5}{*}{$\begin{array}{l}\text { Igbaria et al. } \\
(1997)\end{array}$} & $\begin{array}{l}\text { Amount of training } \\
\text { provided by }\end{array}$ & \multirow{5}{*}{$\begin{array}{l}\text { Perceived ease of use, } \\
\text { perceived usefulness } \\
\text { and system usage }\end{array}$} & $\begin{array}{l}\text { Survey of } 358 \text { users of } \\
203 \text { small firms (managers }\end{array}$ \\
\hline & a other computers & & and non-managers) \\
\hline & $\begin{array}{l}\text { users or computer } \\
\text { specialists in the } \\
\text { company }\end{array}$ & & $\begin{array}{l}\text { Internal EUT has a } \\
\text { positive direct effect on } \\
\text { perceived usefulness, but }\end{array}$ \\
\hline & \multirow{2}{*}{$\begin{array}{l}\text { b friends, vendors, } \\
\text { consultants or } \\
\text { educational } \\
\text { institutions external } \\
\text { to the company }\end{array}$} & & $\begin{array}{l}\text { no effect on perceived } \\
\text { ease of use or system } \\
\text { usage }\end{array}$ \\
\hline & & & $\begin{array}{l}\text { External EUT has a } \\
\text { positive direct effect on } \\
\text { perceived ease of use and } \\
\text { a positive indirect effect } \\
\text { on system usage, but no } \\
\text { effect on perceived } \\
\text { usefulness }\end{array}$ \\
\hline \multirow[t]{2}{*}{$\begin{array}{l}\text { A1-Gahtani and } \\
\text { King (1999) }\end{array}$} & \multirow{2}{*}{$\begin{array}{l}\text { The extent to which } \\
\text { nine different sources } \\
\text { contributed to an } \\
\text { increase in users' } \\
\text { knowledge and } \\
\text { expertise }\end{array}$} & \multirow[t]{2}{*}{ System usage } & $\begin{array}{l}\text { Survey of } 329 \text { final-year } \\
\text { university students having } \\
\text { worked in industry for one } \\
\text { year (junior management) }\end{array}$ \\
\hline & & & $\begin{array}{l}\text { EUT has a direct effect on } \\
\text { system usage }\end{array}$ \\
\hline \multirow[t]{2}{*}{$\begin{array}{l}\text { Gallivan et al. } \\
(2005)\end{array}$} & \multirow[t]{2}{*}{$\begin{array}{l}\text { Amount of user training } \\
\text { and perceived training } \\
\text { quality }\end{array}$} & \multirow[t]{2}{*}{ System usage } & $\begin{array}{l}\text { Survey of } 94 \text { employees } \\
\text { of a non-profit } \\
\text { organisation }\end{array}$ \\
\hline & & & $\begin{array}{l}\text { Amount of user training } \\
\text { and perceived training } \\
\text { quality are unrelated to } \\
\text { system usage }\end{array}$ \\
\hline \multirow[t]{2}{*}{$\begin{array}{l}\text { Rouibah et al. } \\
(2009)\end{array}$} & \multirow{2}{*}{$\begin{array}{l}\text { Questions about the } \\
\text { availability of internal } \\
\text { training, the clarity of } \\
\text { end-users' role and } \\
\text { objectives, adequate } \\
\text { course material, IT } \\
\text { support after training } \\
\text { and training } \\
\text { programmes preceding } \\
\text { effective IS usage }\end{array}$} & \multirow[t]{2}{*}{$\begin{array}{l}\text { System usage, user } \\
\text { satisfaction }\end{array}$} & $\begin{array}{l}\text { Survey of } 382 \text { employees } \\
\text { in the Kuwait public } \\
\text { sector }\end{array}$ \\
\hline & & & $\begin{array}{l}\text { EUT has an indirect effect } \\
\text { on system usage and user } \\
\text { satisfaction }\end{array}$ \\
\hline
\end{tabular}


Waal, B.M.E. de, Batenburg, R. What makes end-user training successful? A mixed method study of a business process management system implementation. International Journal of Knowledge and Learning: 2012, 8(1/2), 166-183

Figure 1 Conceptual model and hypothesis to be tested in this study

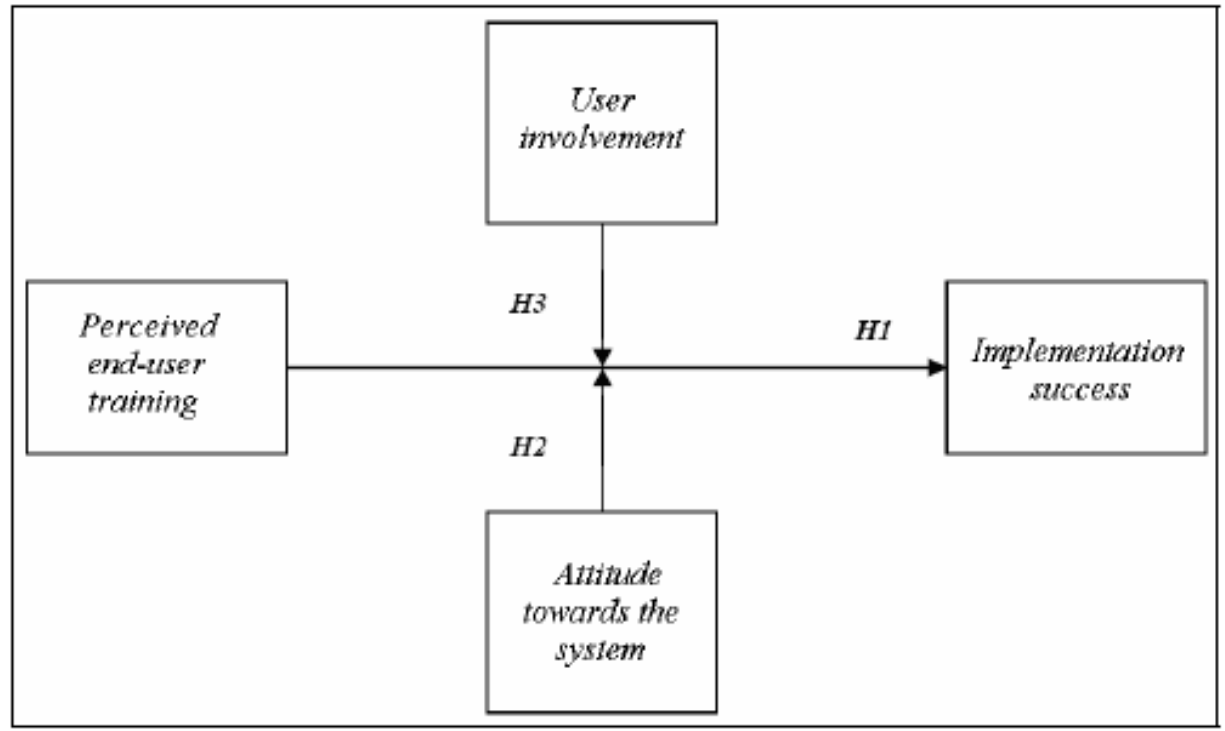

Table 2 Descriptive analysis of implementation success, user involvement, attitude towards the system, and perceived EUT $(\mathrm{N}=143)$

\begin{tabular}{lcccccc}
\hline & $N$ & Min & Max & Mean & $\begin{array}{c}\text { Standard } \\
\text { deviation }\end{array}$ & Skewness \\
\hline Implementation success measured by: & & & & & & \\
- Information satisfaction & 143 & 1.00 & 3.00 & 2.12 & 0.62 & -.317 \\
- Service satisfaction & 143 & 1.00 & 4.00 & 2.43 & 0.56 & -.602 \\
- Intention to use & 143 & 1.00 & 4.00 & 1.63 & 0.73 & .941 \\
User involvement & 143 & 1.00 & 6.80 & 3.26 & 1.53 & .249 \\
Attitudes towards the system & 143 & 1.00 & 6.25 & 3.09 & 1.41 & .155 \\
Perceived EUT & 143 & 1.00 & 4.00 & 2.24 & 0.75 & -.219 \\
\hline
\end{tabular}

Table 3 Regression analysis: predictive power of EUT and implementation success for user involvement and attitude towards the system $(\mathrm{N}=143)$

\begin{tabular}{|c|c|c|c|c|c|c|}
\hline & \multicolumn{6}{|c|}{ IMPLEMENTATION SUCCESS - MEASURED BY: } \\
\hline & \multicolumn{2}{|c|}{ INF_SATISFACTION } & \multicolumn{2}{|c|}{ SERV_SATISFACTION } & \multicolumn{2}{|c|}{ INTENTION_TO_USE } \\
\hline & Coefficient & $p$ & Coefficient & $p$ & Coefficient & $p$ \\
\hline PERCEIVED_EUT $\left(\beta_{1}\right)$ & .17 & .11 & .30 & .00 & -.29 & .01 \\
\hline EUT $\times$ USER_INV $\left(\beta_{2}\right)$ & .25 & .02 & .25 & .01 & .54 & .00 \\
\hline PERCEIVED_EUT $\left(\beta_{1}\right)$ & -.07 & .48 & .16 & .11 & -.55 & .00 \\
\hline EUT $\times$ ATT_SYST $\left(\beta_{2}\right)$ & .57 & .00 & .43 & .00 & .87 & .00 \\
\hline
\end{tabular}


Waal, B.M.E. de, Batenburg, R. What makes end-user training successful? A mixed method study of a business process management system implementation. International Journal of Knowledge and Learning: 2012, 8(1/2), 166-183

Table 4 Summary of the most frequent and prominent statements made during the interviews with users with regard to training $(\mathrm{N}=49)$

\begin{tabular}{|c|c|c|c|c|}
\hline \multirow{2}{*}{$\begin{array}{l}\text { Element } \\
\text { Training } \\
\text { procedure }\end{array}$} & \multirow{2}{*}{$\frac{\text { Function }}{\text { TS }}$} & \multicolumn{2}{|c|}{ \# statements } & \multirow{2}{*}{$\begin{array}{l}\text { Prominent pronouncements of users by job category* } \\
\text { "Gradually, you began to work with the system in the } \\
\text { department, where a trainer and mentors were present" }\end{array}$} \\
\hline & & Pos. & 13 & \\
\hline & & Neg. & 17 & $\begin{array}{l}\text { "In practice it is different. What do you do when you } \\
\text { make a mistake, how can you go back" }\end{array}$ \\
\hline & PS & Pos. & 13 & $\begin{array}{l}\text { "In the workplace, colleagues could contact the } \\
\text { mentors for questions, spread over several days" }\end{array}$ \\
\hline & & Neg. & 25 & "Training could be more practical" \\
\hline & $\mathrm{JC}$ & Pos. & 11 & $\begin{array}{l}\text { "You could put the training directly into practice. It } \\
\text { was well phased" }\end{array}$ \\
\hline & & Neg. & 20 & $\begin{array}{l}\text { "Training on the shop-floor was introduced too early, } \\
\text { there were no cases available" }\end{array}$ \\
\hline & ID & Pos. & 10 & $\begin{array}{l}\text { "During the deployment you got first a special training } \\
\text { and then as a team. This was good" }\end{array}$ \\
\hline & & Neg. & 13 & $\begin{array}{l}\text { "At the training it seems easy. If you are starting work } \\
\text { there still appear all kinds of problems" }\end{array}$ \\
\hline \multirow{8}{*}{$\begin{array}{l}\text { Training } \\
\text { material }\end{array}$} & TS & Pos. & 6 & "Learning material was alright" \\
\hline & & Neg. & 3 & $\begin{array}{l}\text { "The release you worked with in practice, was } \\
\text { different from the release of the training" }\end{array}$ \\
\hline & PS & Pos. & 4 & "Learning material was alright" \\
\hline & & Neg. & 3 & "The learning material did not match the releases" \\
\hline & $\mathrm{JC}$ & Pos. & 2 & "Learning material was alright" \\
\hline & & Neg. & 0 & - \\
\hline & ID & Pos. & 2 & "Generally, the learning material was good" \\
\hline & & Neg. & 4 & "During the training, the manual was not available" \\
\hline
\end{tabular}

Notes: $* \mathrm{TS}=$ team support employee; $\mathrm{PS}=$ process support employee;

$\mathrm{JC}=$ job consultant; $\mathrm{ID}=$ medical insurance doctor . 
Waal, B.M.E. de, Batenburg, R. What makes end-user training successful? A mixed method study of a business process management system implementation. International Journal of Knowledge and Learning: 2012, 8(1/2), 166-183

Table 4 Summary of the most frequent and prominent statements made during the interviews with users with regard to training $(\mathrm{N}=49)$

\begin{tabular}{|c|c|c|c|c|}
\hline \multirow{3}{*}{$\begin{array}{l}\text { Element } \\
\text { Training } \\
\text { environment }\end{array}$} & \multirow{2}{*}{$\frac{\text { Function }}{\text { TS }}$} & \multicolumn{2}{|c|}{ \# statements } & \multirow{2}{*}{$\begin{array}{l}\text { Prominent pronouncements of users by job category* } \\
\text { "The computers and course material were in order" }\end{array}$} \\
\hline & & Pos. & 2 & \\
\hline & & Neg. & 8 & "There were many computer failures during training" \\
\hline & PS & Pos. & 3 & "The learning environment was all right" \\
\hline & & Neg. & 9 & $\begin{array}{l}\text { "The training environment was susceptible to } \\
\text { malfunction" }\end{array}$ \\
\hline & $\mathrm{JC}$ & Pos. & 2 & "The training went just fine, there were no failures" \\
\hline & & Neg. & 6 & $\begin{array}{l}\text { "The computer system did not work always, therefore } \\
\text { it was to improvise" }\end{array}$ \\
\hline & ID & Pos. & 1 & "The computing environment was generally good" \\
\hline & & Neg. & 6 & $\begin{array}{l}\text { "During the } \mathrm{D} \text { training days, computers were slowly } \\
\text { or did not work" }\end{array}$ \\
\hline \multirow[t]{8}{*}{ Time } & TS & Pos. & 2 & "The training was long, one day" \\
\hline & & Neg. & 6 & $\begin{array}{l}\text { "The training was too small, too short, below } \\
\text { standard" }\end{array}$ \\
\hline & PS & Pos. & 1 & "The training was 1.5 days, this was sufficient" \\
\hline & & Neg. & 10 & $\begin{array}{l}\text { "The system is so complex that you can't learn this in } \\
\text { just one afternoon" }\end{array}$ \\
\hline & $\mathrm{JC}$ & Pos. & 3 & "Enough time, 2 to 3 days" \\
\hline & & Neg. & 3 & "The time they have got was definitely insufficient" \\
\hline & ID & Pos. & 0 & - \\
\hline & & Neg. & 2 & $\begin{array}{l}\text { "You had one day course. This is too little, the reality } \\
\text { is different. It's not just clicks, you can quickly do } \\
\text { something wrong" }\end{array}$ \\
\hline \multirow[t]{8}{*}{ Trainers } & TS & Pos. & 2 & "The trainers were good" \\
\hline & & Neg. & 2 & $\begin{array}{l}\text { "The trainers were available every week. They knew } \\
\text { however no answer to practical questions" }\end{array}$ \\
\hline & PS & Pos. & 2 & "The trainers were well informed" \\
\hline & & Neg. & 6 & $\begin{array}{l}\text { "The trainers did not have enough practical } \\
\text { knowledge. On practical questions they had no } \\
\text { answers" }\end{array}$ \\
\hline & $\mathrm{JC}$ & Pos. & 2 & "The trainers were qualified" \\
\hline & & Neg. & 6 & $\begin{array}{l}\text { "The trainers had no knowledge of the work of the job } \\
\text { consultant and could therefore not demonstrate the } \\
\text { added value" }\end{array}$ \\
\hline & ID & Pos. & 3 & $\begin{array}{l}\text { "The trainers knew well how the system was put } \\
\text { together" }\end{array}$ \\
\hline & & Neg. & 1 & $\begin{array}{l}\text { "During the deployment, the trainers were not } \\
\text { knowledgeable enough" }\end{array}$ \\
\hline
\end{tabular}

Notes: $*$ TS $=$ team support employee; $\mathrm{PS}=$ process support employee; $\mathrm{JC}=$ job consultant $\mathrm{ID}=$ medical insurance doctor. 